\title{
Epidemiological profile of maternal deaths in a referral hospital for high-risk pregnancy
}

\author{
Perfil epidemiológico dos óbitos maternos em hospital de referência para gestação de alto \\ risco
}
Perfil epidemiológico de las muertes maternas en hospital de referencia para embarazos de alto

Maria Lúcia Neto Menezes ${ }^{1}$, Joana de Faria Oliveira Bezerra² ${ }^{2}$ Julia de Faria Oliveira Bezerra²

Objective: to describe the epidemiological profile of maternal deaths in a referral public hospital. Methods: it is a retrospective, descriptive study of cross-section type. Variables in the death certifications and maternal death investigation forms were analyzed. Results: there were 93 cases recorded, corresponding to the ratio of 228.4 maternal deaths per 100,000 live births. Most of these deaths were from women aged 20-29 years old (47.3\%), undergoing cesarean section (39.8\%). Most deaths occurred in the postpartum period (66.7\%), by direct obstetric causes (55.9\%), especially: infection (28.0\%), cardiovascular disease $(20.4 \%)$ and lung disease $(10.8 \%)$. Conclusion: maternal deaths occurred in a context of socio-economic unfavorable condition, especially affecting young women, black, victimized by infectious conditions and cardiovascular diseases. The importance of improving the quality of records, surveillance deaths and postnatal care were evident.

Descriptors: Maternal Mortality; Pregnancy, High-Risk; Epidemiological Surveillance.

Objetivo: caracterizar o perfil epidemiológico dos óbitos maternos de um hospital público de referência. Métodos: estudo retrospectivo e descritivo do tipo corte transversal. Foram analisadas variáveis contidas nas declarações de óbito e fichas de investigação de óbito materno. Resultados: registraram-se 93 casos, correspondendo à razão de 228,4 óbitos maternos por 100 mil nascidos vivos. Prevaleceram mulheres entre 20 a 29 anos (47,3\%), submetidas à cesariana (39,8\%). A maioria dos óbitos ocorreu no puerpério $(66,7 \%)$, por causas obstétricas diretas $(55,9 \%)$, predominando: infecção $(28,0 \%)$, doenças cardiovasculares $(20,4 \%)$ e doenças pulmonares (10,8\%). Conclusão: a morte materna ocorreu em um contexto de condição socioeconômica desfavorável, atingindo especialmente mulheres jovens, negras, vitimizadas por quadros infecciosos e doenças cardiovasculares. Foi evidente a importância da melhoria da qualidade dos registros, da vigilância de óbitos e assistência pós- natal.

Descritores: Mortalidade Materna; Gravidez de Alto Risco; Vigilância Epidemiológica.

Objetivo: caracterizar el perfil epidemiológico de la mortalidad materna de un hospital público de referencia. Métodos: estudio retrospectivo, descriptivo del tipo transversal. Se analizaron variables contenidas en las declaraciones de muerte y fijas de investigación de muerte materna. Resultados: 93 casos se registraron, correspondientes a la relación de 228,4 muertes maternas por 100.000 nacidos vivos. Prevalecieron mujeres de 20-29 años (47,3\%), sometidas a cesárea (39,8\%). La mayoría de las muertes ocurriera en el post-parto $(66,7 \%)$, por causas obstétricas directas $(55,9 \%)$, predominantemente: infección (28,0\%), enfermedades cardiovasculares (20,4\%) y enfermedad pulmonar (10,8\%). Conclusión: la muerte materna ocurrió en un contexto de condición socioeconómica desfavorable, afectando especialmente a las mujeres jóvenes, negros, víctimas de enfermedades infecciosas y cardiovasculares. Fue visible la importancia de la mejora de la calidad de los registros, de la vigilancia de muertes y atención postnatal.

Descriptores: Mortalidad Materna; Embarazo de Alto Riesgo; Vigilancia Epidemiológica.

\footnotetext{
${ }^{1}$ Universidade de Pernambuco, Faculdade de Enfermagem Nossa Senhora das Graças. Recife, PE, Brazil.

${ }^{2}$ Hospital Agamenon Magalhães, Recife, PE, Brazil. 


\section{Introduction}

Maternal mortality mainly occurs in developing countries and it is considered a preventable tragedy in $92 \%$ of cases. Thus, it is one of the most serious violations of women human rights ${ }^{(1-2)}$. According to the World Health Organization, about 287,000 women worldwide died in 2010, victims of complications related to pregnancy and childbirth. The Maternal Mortality Ratio in developing countries was 15 times higher than in developed countries ${ }^{(3)}$.

Maternal death is defined as the woman's death during pregnancy or within 42 days after pregnancy finished, regardless the duration or location of the pregnancy. Maternal death is considered when any factor related or aggravated by pregnancy or by measures taken for $\mathrm{it}^{(2)}$.

In Latin America, approximately 15,000 women die each year from complications in pregnancy, childbirth or postpartum period. Developed countries like Canada and the United States have lower values than 11 maternal deaths per 100,000 live births. Developing countries like Bolivia and Peru reach more than 200 deaths and Haiti has a maternal mortality ratio of 670 maternal deaths per 100000 live births. Despite the economic situation of the country is a great indicator of maternal death rates, there are countries such as Cuba and Costa Rica, where maternal mortality ratios are substantially lower, showing that maternal deaths are also related warranty policies of women's health during pregnancy and postpartum ${ }^{(1)}$.

In 2012, Brazil presented a Maternal Mortality Ratio of 54.5 deaths per 100,000 live births ${ }^{(2)}$. The World Health Organization, establishing as acceptable 20 maternal deaths per 100,000 live births, considers this value as high. The index between 20 and 49 deaths are considered average, between 50 and 149 deaths is considered high and above 150 it is very high ${ }^{(4)}$.

The Maternal Mortality Reason is used to indicate poverty, social inequity, coverage and quality of medical and health care of a population. Between 1990 and 2010, the Ministry of Health recorded a 50\% reduction in the number of maternal deaths. Despite this great achievement, Brazil must still attain the rate of 35 maternal deaths per 100,000 live births by 2015 to achieve fifth Millennium Development Goal of the United Nations ${ }^{(4)}$.

In this context, this study allows a view of the epidemiological profile of deaths in a referral hospital for high-risk pregnancies in the city of Recife-PE. The results of this study may contribute to increased knowledge on the subject, facilitating the early identification of predisposing factors for maternal death and therefore, they may help to reduce the number of maternal deaths since most of these causes are preventable. Studies like this are important to contribute to the implementation of actions to improve the care and prevention and control of pregnancy and puerperal diseases in pregnant women and mostly in women more susceptible to the risk of maternal death.

This study aimed to characterize the epidemiology of maternal deaths in Agamenon Magalhães Hospital.

\section{Method}

This is a retrospective, descriptive and quantitative, cross-section type of maternal death cases occurred at Agamenon Magalhães Hospital, in the period from 2003 to 2013. This study was developed from information obtained from death certifications and maternal death investigation forms. Data collection was carried out between September and December 2014.

The research field was the Agamemnon Magalhães Hospital, located in the metropolitan area of Recife, the capital of Pernambuco. This Hospital is a referral public institution of the state in highrisk pregnancy, which performs about 320 monthly procedures in the delivery room, with 87 beds, being 12 for expectation, 17 for high risk, 10 for kangaroo method and 48 for rooming-in.

The study population consists of all cases of maternal deaths reported in the Agamenon Magalhães 
Hospital, from January 01, 2003 to December 31, 2013.

As inclusion criteria, there were maternal deaths from direct or indirect obstetric causes, regardless the duration or location of the pregnancy ${ }^{(2)}$ and as exclusion criteria, there were maternal deaths for non-obstetric causes.

To operationalize this study, the following variables were analyzed: Annual Maternal Mortality Ratio of maternal deaths, age, years of potential life lost, race, marital status, education, residence city, prenatal care, delivery type and cause of death. To obtain the ratio of maternal mortality, deaths classified in Chapter XV of the tenth revision of the International Classification of Diseases (ICD-10) were considered, except 096 and 097 codes (late maternal death and death from sequelae of direct obstetric causes). The calculation of the Maternal Mortality Ratio was conducted by dividing maternal deaths by the number of live births and multiplying by $100,000^{(1)}$. The Maternal Mortality Ratio was calculated for each year and for the entire period of the study and the evolution analysis was performed by the graphical representation of the trend curve.

To calculate the Potential Years of Life Lost ${ }^{(5)}$, the recommendations of the Ministry of Health of Brazil were used. Therefore, the average age of each group was calculated, then, these averages were subtracted from the age limit of 70 years old. Then, the number of deaths in each age group was multiplied by the number of years missing to reach the age limit of 70 years old. The sum of these products provides total potential years of life lost.

The categorization of variables was adjusted according to the items in the death certification and the maternal death investigation forms that are filled by death investigator and filed by the Epidemiology center of the Agamenon Magalhães Hospital.

This study does not provide any kind of risk to the subjects in this research and by using secondary data, the free and informed form was not needed. The authors ensure the confidentiality and secrecy of the data, according to Resolution 466/12 of the National Health Council guidelines. The project of this study was approved by the Ethics Committee in Research of the University of Pernambuco, by opinion number: 577,305 .

\section{Results}

There were 93 maternal deaths in the decade studied, corresponding to a Maternal Mortality Ratio of 228.46 per 100,000 live births. The trend line of the decade deaths was decreasing. The year 2004 had the highest Maternal Mortality Ratio to 483.51 and the year 2007 had the slightest ration to 66.64 deaths per 100,000 live births (Figure 1).

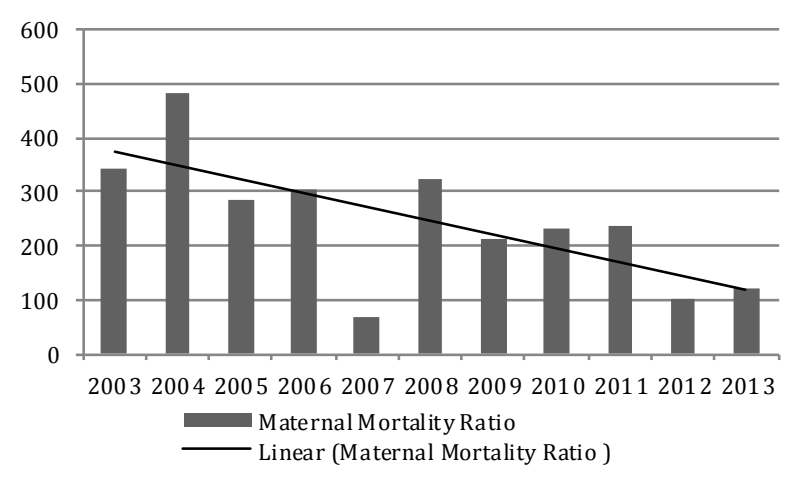

Figure 1 - Maternal Mortality Ratio in the Agamenon Magalhães hospital

The age group with the highest number of cases of maternal death was from 20 to 29 years old representing $47.3 \%$ of cases, followed by the age group from 30 to 39 years old with $28 \%$ of cases. The third highest percentage (16.1\%) were in women aged 1019 years old and in last place (6.5\%) there were those from 40 to 49 years old (Table 1). The total maternal deaths in the period had 3959 potential years of life lost, corresponding to 792 years of potential life lost for the age group between 10-19 years, 1997 to 20-29 years, 999 for 30 to 39 years and, finally, 171 between 40 and 49 years.

Most deaths occurred in black women with $45.1 \%$; white represented $20.4 \%$ of total cases, being 
important to highlight that in the remaining $34.4 \%$, their form filled was ignored (Table 1).

Regarding marital status, it was observed a high number of ignored records (63.4\%). Among the valid data, single mothers (20.4\%) prevailed over married $(16.1 \%)$ and there were no cases of widows and separated women.

Among the occupations mentioned in the death records, the number of housewives was highlighted (14.0\%), followed by farmers and students with the same number of cases (7.0\%), domestic (6.5\%) and shopkeepers (3.2\%). Education was the variable with the highest number of ignored cases (68.8\%). Among the records, those who had 1-3 years of education $(10.8 \%)$ had the highest number of cases followed by those with 4 to 7 and 8 to 11 years of study, showing the same proportion (6.5\%). The percentage of illiterate corresponded to $5.4 \%$ and those who studied for 12 years or more had $2.2 \%$ of the victims (Table 1 ).

Table 1 - Epidemiological characteristics of maternal deaths in the Agamenon Magalhães hospital

\begin{tabular}{lc}
\hline Characteristics & $\mathbf{n ( \% )}$ \\
\hline Race & \\
White & $19(20.4)$ \\
Black & $42(45.1)$ \\
Ignored & $32(34.4)$ \\
Age group (years) & \\
10 to 19 & $15(16.1)$ \\
20 to 29 & $44(47.3)$ \\
30 to 39 & $28(30.1)$ \\
40 to 49 & $6(6.5)$ \\
Education (years) & \\
No education & $5(5.4)$ \\
1 to 3 & $10(10.8)$ \\
4 to 7 & $6(6.5)$ \\
8 to 11 & $6(6.5)$ \\
12 and more & $2(2.2)$ \\
Ignored & $64(68.8)$ \\
Marital status & \\
Single & $19(20.4)$ \\
Married & $15(16.1)$ \\
Ignored & $59(63.4)$ \\
Origin & \\
Recife & $27(29)$ \\
Metropolitan Region of Recife & $34(36.5)$ \\
Other cities in Pernambuco & $32(34.4)$ \\
\hline
\end{tabular}

Among the women who died from obstetric causes, $29.0 \%$ were residents of Recife, $36.5 \%$ lived in the metropolitan area of Recife and $34.4 \%$ in other cities in the state of Pernambuco. Among the cities with the highest number of cases, there are Olinda (8.6\%), Jaboatão dos Guararapes (5.4\%), Cabo de Santo Agostinho (5.4\%) and Paulista (4.3\%) (Data not shown graphically).

In the prenatal care, $65.6 \%$ of the records have not filled this data. Among those who carried out the consultation, only $34.4 \%$ had complete prenatal, as recommended by the Ministry of Health (minimum of 6 visits), the remaining $65.6 \%$ had incomplete prenatal care ${ }^{(6)}$.

The most common type of birth was a cesarean section with $39.8 \%$ of the records and the same percentage had ignored cases. Normal deliveries were $20.4 \%$ of the sample.

It was found that $66.7 \%$ of the deaths occurred in the postpartum period; $24.7 \%$ of deaths were during pregnancy; $7.5 \%$ of deaths in the late postpartum period and $1.1 \%$ of deaths at delivery. Among the causes of death, $55.9 \%$ were considered direct deaths; $34.4 \%$ were indirect deaths and $9.7 \%$ were not clear. The most prevalent deaths were infectious causes (28.0\%), followed by cardiovascular disease (20.4\%) and pulmonary diseases (10.8\%). Cases referred to the Death Verification Service (21.5\%) were not considered.

\section{Discussion}

High-risk hospitals tend to have a higher maternal mortality rate when compared to lowrisk maternity hospitals ${ }^{(7)}$. This occurs because they are referral centers for severe cases, through the various cities in the state. However, considering that the World Health Organization accepts a limit of 20 deaths per 100,000 live births ${ }^{(4)}$, this study showed very high levels of Maternal Mortality Ratio. This is worrying because maternal mortality is one of the most important health indicators of the population 
and these data indicate the need for actions aimed at improving the quality of reproductive health.

The trend line of Maternal Mortality Ratio kept is decreasing over the study period, similar data to what is shown in the research of the Ministry of Health and the Institute of Applied Economic Research, showing decreasing values by $2010^{(8-9)}$. There are few studies that show the trend of Maternal Mortality Ratio after 2010 in the country and in the state of Pernambuco. Nevertheless, it is known that Brazil is the fourth slowest country in reducing maternal mortality ${ }^{(10)}$ through research conducted by the United Nations with the participating countries of the millennium goals in 2000 to 2013.

Maternal Mortality Ratio reduction has occurred because the measures adopted by the Unified Health System as the regulation of surveillance of maternal deaths and implementation of improving maternal health policies, highlighting the Cegonha Network ${ }^{(9)}$. Cegonha Network is a Ministry of Health strategy aiming at ensuring women's right to reproductive planning and humanized care to pregnancy, childbirth and the postpartum period, and ensuring every child's right to a safe birth and healthy growth and development ${ }^{(11)}$.

It is important to highlight the number of information not recorded on death certifications and the maternal mortality investigation forms, making difficult to analyze and discuss the results, decreasing the accuracy of information useful to trace the epidemiological profile. Failure in the information record pattern occurred in many studies involving secondary database ${ }^{(12-14)}$. The variables with the greater incompleteness of the cases were race, education, marital status, occupation and prenatal care. Despite that fact, it should be noted that from 2008, there was a significant improvement in filling the data of maternal death investigation forms due to a greater commitment by the professionals in the hospital epidemiology center.
Research related to problems in filling out the death certifications noted that some of the main problems leading to lack of information are: large number of gaps to be filled, failure in the dissemination of instructions for filling out that gaps, lack of enough information for physicians to register the death and ignorance by physicians of the importance of proper completion of the form for the accuracy and consistency of information ${ }^{(15)}$.

Only the medical professional must fill out the death certifications. However, this study also identified investigation records being responsibility by other health professionals ${ }^{(1)}$. This fact shows the need that there is a higher charge for the proper and complete filling of information and dissemination of the importance of this act so that the actual identification of feasible profile of these women and the consequent implementation of effective measures to minimize the risk of maternal deaths preventable.

Several studies show a higher prevalence of maternal mortality among young adults, that is, from 20 to 34 years old ${ }^{(12-13,16)}$. The age group of 20 to 29 years old had more than half of the total potential years of life lost accounted in this study. This prevalence is due to be the age group where there is highest fertility rate in $\mathrm{Brazil}^{(17)}$.

It was also noteworthy the number of cesarean deliveries in cases of deaths. However, it should be considered that this is a high-risk maternity with higher indications for termination of pregnancy because of risk factors for the mother and the fetus. Cesareans are common in Brazil and can be observed in other states as most births ${ }^{(12-13,18)}$. It is known that this high number hinder to reduce maternal mortality in the country and its percentage has remained at very high levels and growth trend in all regions ${ }^{(9)}$.

The World Health Organization recommends that the percentage of cesarean does not exceed $15 \%$ of total births. This policy is from the fact that indiscriminate performing this procedure offers the 
mother 3.5 times greater risk of dying and five times more likely to contract a puerperal infection, and provide unnecessary risks to the child ${ }^{(9)}$.

Most of the cases were women living in the metropolitan area of Recife, but a significant amount came from other mesoregions of the state of Pernambuco. A research in the city of Aracajú showed a similar profile, reporting high demand of patients living in the interior of the state, overloading health services in large urban centers and the capital ${ }^{(14)}$. This context suggests that many patients go searching for access to a high-risk care and end up overcrowding complex maternities, reaching sometimes to situations that are more serious.

In several studies, as well as this one, there is a predominance of maternal mortality from direct obstetric causes ${ }^{(2,8,12-14)}$. These deaths are mostly preventable through health education, prenatal care quality and adequate hospital obstetric care ${ }^{(12)}$. In Brazil, the major causes of maternal death are for hypertensive disorders, bleeding and infectious ${ }^{(1)}$, which differs from the findings of this study showing that the main causes of the infections followed heart and lung diseases.

In addition, there were large numbers of deaths due to puerperal infection. Some of the risk factors related to puerperal infection are amniorrhexis, prolonged delivery labor, malnutrition or obesity, excessive vaginal manipulation, surgical trauma, poor aseptic conditions, cesarean, immune weakness and retention of ovular remains ${ }^{(19)}$. An integrative review study showed the importance of the nurse's role in the control of these infections, citing as main actions to the frequent assessment of vital signs, constant listening to the complaints of mothers and provision of adequate care surgical incisions ${ }^{(20)}$. In addition to these factors, it is important to emphasize health education as a very effective strategy, since the guidance to return to the hospital in case of appearance of signs of infection, the care of the surgical wound and proper hygiene of the genital region, enable prevention of puerperal infections.

\section{Conclusion}

Maternal deaths occurred in a context of socio-economic unfavorable condition, especially affecting young women, black, victimized by infectious conditions and cardiovascular diseases. The importance of improving the quality of records, surveillance deaths and postnatal care were evident.

For the occurrence of postpartum deaths, it is important the postpartum monitoring (postnatal), considering that this period has risk factors and complications that may progress to death as cases in this study.

The Maternal Mortality Ratio has been reduced over the years, however, it still prevails as a public health problem. Brazil does not reach the goal of the millennium goals proposed for 2015, so it is necessary to intensify efforts in the investigation and surveillance of maternal deaths and encourage health education and the creation and execution of public policies to ensure the right to health of women during pregnancy and childbirth.

\section{Acknowledgements}

To the epidemiology center of the Hospital Agamenon Magalhães, providing their database.

\section{Collaborations}

Menezes MLN contributed with the project elaboration, research guiding, article construction and final review to be published. Bezerra JFO e Bezerra JFO participated in the elaboration of the research project, data analysis, article construction and final review. 


\section{References}

1. Ministério da Saúde (BR). Secretaria de Vigilância em Saúde, Departamento de Análise de Situação em Saúde. Guia de vigilância epidemiológica do óbito materno. Brasília: Ministério da Saúde; 2009.

2. Áfio ACE, Araújo MAL, Rocha AFB, Andrade RFV, Melo SP. Maternal deaths: the need to rethink coping strategies. Rev Rene. 2014; 15(4): 631-8.

3. World Health Organization. Trends in Maternal Mortality: 1990 to 2010:WHO, UNICEF, UNFPA and The World Bank estimates. [Internet] 2012 [cited 2014 feb 25]. Available from: http://whqlibdoc. who.int/publications/2012/9789241503631_ eng.pdf

4. Secretaria de Saúde do Estado do Ceará. Informe epidemiológico mortalidade materna: 2014. Fortaleza: SESA; 2014.

5. Silva LS, Menezes MLN, Lopes CLA, Corrêa MSM. Anos potenciais de vida perdidos por mulheres vítimas de homicídio na cidade do Recife, Pernambuco, Brasil. Cad Saúde Pública. 2011; 27(9):1721-30.

6. Ministério da Saúde (BR). Secretaria de Atenção à Saúde. Caderno de Atenção Básica: Atenção ao pré-natal de baixo risco. Brasília: Ministério da Saúde; 2012.

7. Soares VMN, Souza KV, Azevedo EMM, Possebon CR, Marques FF. Causas de mortalidade materna segundo níveis de complexidade hospitalar, Brasil. Rev Bras Ginecol Obstet. 2012; 34(12):53643.

8. Souza JP. Mortalidade materna e desenvolvimento: a transição obstétrica no Brasil. Rev Bras Ginecol Obstet. 2013; 35(12):533-5.

9. Instituto de Pesquisa Econômica Aplicada e Secretaria de Planejamento e Investimentos Estratégicos. Objetivos de desenvolvimento do milênio: relatório nacional de acompanhamento. Brasília: IPEA; 2014.
10. Partnership for Maternal, Newborn \& Child Health (PMNCH) 2014 Partners' Forum Media Roundup 30 June - 1 July 2014. Media coverage as of 10:00PM, EST 8 July, 2014. [Internet] 2014 [cited 2014 feb 25]. Available from: http://www.who. int/pmnch/about/governance/partnersforum/ media_coverage.pdf

11. Martinelli GM, Santos Neto ET, Gama SGN, Oliveira AE. Adequacy process of prenatal care according to the criteria of Humanizing of Prenatal Care and Childbirth Program and Stork Network. Rev Bras Ginecol Obstet. 2014; 36 (2):56-64.

12. Herculano MMS, Veloso LS, Teles LMR, Oriá MOB, Almeida PC, Damasceno AKC. Maternal deaths at a public maternity hospital in Fortaleza: an epidemiological study. Rev Esc Enferm. 2012; 46(2):259-301

13. Leite RMB, Araújo TVB, Albuquerque RM, Andrade ARS, Duarte Neto PJ. Fatores de risco para mortalidade materna em área urbana do Nordeste do Brasil. Cad Saúde Pública. 2011; 27(10):197785.

14. Borges CLMS, Costa MCN, Mota ELA, Menezes GMS. Evolução temporal e diferenciais intra-urbanos da mortalidade materna em Aracaju, Sergipe, 20002010. Epidemiol Serv Saúde. 2013; 2(22):307-16.

15. Mendonça FM, Drumond E, Cardoso AMP. Problemas no preenchimento da Declaração de Óbito: estudo exploratório. Rev Bras Est Pop. 2010; 27(2):285-95.

16. Correia RA, Araújo HC, Furtado BMA, Bonfim C. Características epidemiológicas dos óbitos maternos ocorridos em Recife, PE, Brasil (20002006). Rev Bras Enferm. 2011; 64(1):91-7.

17. Ministério do Planejamento Orçamento e Gestão (BR). Instituto Brasileiro de Geografia e Estatística. Projeções da População. Brasil e Unidades da Federação. Brasília: Ministério do Planejamento Orçamento e Gestão; 2013.

18. Troncon JK, Quadros Netto DL, Rehder PM, Cecatti JG, Surita FG. Mortalidade materna em um centro de referência do Sudeste Brasileiro. Rev Bras Ginecol Obstet. 2013; 35(9):388-93. 
19. Benincasa BC, Walker C, Cioba C, Rosa CCS, Martins DE, Dias E, et al. Taxas de infecção relacionadas a partos cesáreos e normais no Hospital de Clínicas de Porto Alegre. Rev HCPA. 2012; 31(1):5-9.
20. Duarte MR, Chrizostimo MM, Christovam BP, Ferreira SCM, Souza DF, Rodrigues DP. Nursing practice on puerperal infection control: integrative review. Rev Enf UFPE On Line. [periódico na Internet]. 2014 [cited 2014 feb 25]; 8(2):43341. Available from: http://www.revista.ufpe.br/ revistaenfermagem/index.php/revista/article/ view/5332/pdf_4606 